\title{
Pengendalian Hama Penyakit Terpadu untuk Mengurangi Kerusakan pada Tanaman Padi di Desa Mekar Sari Kecamatan Gunung Sari
}

\author{
Made Suma Wedastra*, I Dewa Gede Suartha, Theresia Suzanna Catharina, \\ Ida Ayu Ketut Marini, Ni Wayan Putu Meikapasa, Ida Ayu Nopiari \\ Program Studi Agribinis Kampus Mataram, Fakutas Pertanian UNMAS Denpasar
}

Article history

Received: 2019

Revised: 2019

Accepted: 2020

*Corresponding Author:

Made Suma Wedastra

Program Studi Agribinis Kampus

Mataram, Fakutas Pertanian

UNMAS Denpasar,

Indonesia;

Email:

madesumawedastra17@gmail.com
Abstract: Until now farmers still use synthetic chemical pesticides in eradicating pests and diseases. On the one hand, the use of synthetic chemical pesticides is beneficial because of the poison power or the ability to kill pests and diseases that are high and fast, but the excessive use of toxic pesticides, in addition to the increasingly resistant pests and diseases to pesticide poisons, can also pollute the environment. In addition, pesticide poisons tend to increase in price, so that economically it does not increase production value. Community service is carried out in the form of agricultural counseling, carried out in Mekar Sari Village, Gunung Sari District, aiming that farmers have better knowledge and are willing to implement integrated pest and disease control (IPM) methods on rice plants. This counseling material was delivered with lecture techniques, then followed by question and answer sessions. The agricultural extension activities in Mekar Sari Village, Gunung Sari Subdistrict went smoothly and most of the extension participants were able to increase their knowledge to be better, so that they were expected to increase their understanding and be able to apply the technology.

Keywords: integrated; pest; disease control; rice; plants

Abtrak: Sampai saat ini petani masih menggunakan pestisida kimia sintetis dalam pemberantasan hama dan penyakit, karena dianggap lebih menguntungkan sehubungan daya racun atau daya bunuh hama dan penyakit yang tinggi dan cepat, namun penggunaan racun pestisida yang berlebihan, selain semakin resistennya hama dan penyakit terhadap racun pestisida, juga dapat mencemari lingkungan. Selain itu juga racun pestisida cenderung harganya meningkat, sehingga secara ekonomis tidaklah memberikan peningkatann nilai produksi. Pengabdian masyarakat yang dilaksanakan dalam bentuk penyuluhan pertanian, dilaksanakan di Desa Mekar Sari, Kecamatan Gunung Sari, bertujuan agar petani memiliki pengetahuan yang lebih baik dan mau menerapkan cara pengedalian hama dan penyakit terpadu (PHT) pada tanaman padi. Materi penyuluhan ini disampaikan dengan teknik ceramah, kemudian disusul dengan sesi tanya jawab. Kegiatan penyuluhan pertanian di Desa Mekar Sari Kecamatan Gunung Sari berjalan dengan lancar dan sebagian besar peserta penyuluhan dapat meningkatkan pengetahuan menjadi lebih baik, sehingga diharapkan dapat meningkatkan pemahamannya dan mampu menerapkan teknologi tersebut.

Kata Kunci: pengendalian; hama; penyakit; tanaman padi. 


\section{PENDAHULUAN}

Penduduk Indonesia sebagian besar mengkonsumsi beras sebagai bahan makanan pokok sehari-hari, karena itu penyediaan beras merupakan masalah nasional dari tahun ke tahun.

Jumlah beras yang di butuhkan terus meningkat, hal ini di sebabkan oleh laju pertumbuhan penduduk yang semakin meningkat yang di ikuti oleh permintaan beras yang semakin meningkat pula. Selain itu harga beras cenderung meningkat, sehingga di perlukan usaha-usaha untuk meningkatkan produksi tanaman pangan khususnya beras.

Usaha-usaha yang telah dilaksanakan oleh pemerintah dalam meningkatkan produksi beras, selain dengan penambahan areal tanam (ekstensifikasi), juga dengan dengan meningkatkan modal untuk membeli sarana produksi dan peningkatan skill, sehingga produksi dapat meningkat persatuan luas. Cara ini disebut dengan intensifikasi, yaitu dengan menerapkan panca usahatani yang lebih sempurna.

Salah satu kegiatan dalam panca usahatani adalah pengedalian hama dan penyakit. Pengedalian hama dan penyakit yang umum di terapkan sampai saat ini oleh petani adalah dengan penggunaan pestisida kimia sintetik.

Desa Mekar Sari Kecamatan Gunung Sari Kabupaten Lombok Barat, yang merupakan desa binaan KKN Tematik Universitas Mahasaraswati Denpasar Kampus Mataram. Pada saat melaksanakan observasi, masih banyak menemukan petani dalam melaksanaan pemberantasan hama dan penyakit menggunakan pestisida kimia sintetis.

Menurut Untung (2000) penggunaan pestisida di satu pihak memang menguntungkan karena daya racunnya atau daya bunuh hama dan penyakit yang tinggi dan cepat, perspektrum lebar sehingga dapat mematikan banyak jenis hama dan memusnakan penyakit, penggunaannya praktis dan lentur sehingga dapat di sesuaikan dengan keadaan. Namun penggunaan pestisida atau insektisida yang berlebihan dan tidak terkendali akan mencemari lingkungan.

Selama ini petani seringnya mengendalikan hama perusak, pengganggu, dan penyebab penyakit tanaman dengan menyemprotkan pestisida. Cara ini memang bisa dibilang efektif. Pestisida mampu membunuh segala jenis hama yang mengancam hasil panen petani. Namun, pestisida juga menyebabkan masalah pencemaran di lingkungan. Residu pestisida yang disemprotkan ke tanaman tidak akan hilang secepatnya, bahkan mencapai seminggu setelah penyemprotan.

Perubahan sosial kemasyarakatan di negara berkembang telah menimbulkan dampak yang luas terhadap perubahan jenis, tingkat serangan, perkembangan, dan laju penyebaran penyakit tanaman. Puluhan penyakit dilaporkan mengancam tanaman pangan yang dibudidayakan termasuk padi. Setiap patogen dapat mengganggu lebih dari satu varietas tanaman padi, dan setiap varietas tanaman padi dapat diinfeksi oleh lebih dari satu jenis patogen. Penyakit juga dapat merusak pada bagian organ tertentu atau bahkan ke seluruh organ tanaman (Semangun, 2008).

Di Indonesia, penyakit penting tanaman padi adalah hawar daun bakteri(Xa ntho mona $s$ campestris p v. oryzae), penyakit tungro (virus tungro), bercak daun $\mathrm{p} \mathrm{yr}$ icul ar ia ( $P$ yr icu la ria $g$ rise a), b usuk batang (Helminthosporium sigmoideun), hawar pelepah daun (Rhizoctonia solani kuhn), kerdil hampa (Reget stunt) dan kerdil rumput (Grassy stunt) (Semangun 2008).

Penggunaan racun pestisida yang berlebihan, bukannya bisa membunuh dan membrantas hama dan penyakit, bahkan hama dan penyakit semakin resisten (tahan) terhadap racun pestisida (Untung, 2000). Selain itu juga racun pestisida atau insektisida harganya tidaklah murah, bahkan harga terus meningkat, apalagi tidak adanya subsidi harga obat dari pemerintah. Dengan penggunaan 
pestidia sintetis biaya produksi meningkat 25 persen (Nuryanto, 2018), sehingga secara ekonomis tidaklah memberikan peningkatan nilai produksi yang tinggi.

Lebih lanjut Nuryanto (2018), menyatakan bahwa penggunaan pestisida sudah terbukti mencemari lingkungan, terutama jika diaplikasikan secara tidak terkendali. Manipulasi lingkungan atau rekayasa ekologi berpeluang menekan perkemban gan penyakit tanaman. Hal ini dapat dilakukan dengan mengelola komponen budidaya secara selektif, di antaranya pemilihan varietas tahan, penggunaan benih sehat, pengolahan tanah sempurna, penggunaan bahan organik, keserempakan tanam pada waktu yang tepat, pemupukan berimbang dan pengaturan pengairan tanaman. Selain efektif, teknologi pengendalian penyakit berdasarkan komponen epidemik ini juga dapat menekan biaya produksi hingga 60\% dan mengurangi tingkat kehilangan hasil padi sampai $30 \%$.

Kendala dan masalah yang dihadapi dalam praktek budi daya padi semakin beragam. Konversi lahan sawah di sentra penghasil padi masih terus berlangsung. Perubahan iklim global yang berdampak terhadap anomali iklim mendorong perkembangan hama dan penyakit yang mengancam keselamatan produksi padi. Akibatnya, keuntungan usaha tani menurun karena harus dikurangi dengan biaya pengendalian hama penyakit yang semakin tinggi dan kualitas produksi pun menurun sehingga kalah bersaing di pasar (Cantrell 2004).

Selain itu juga banyak letusan hama tanaman akhir-akhir ini yaitu akibat penggunaan pestisida kurang tepat, sehingga cendrung berlebihan dan tidak mengenai sasaran. Penggunaan yang semula di tujukan untuk mengurangi populasi hama tetapi karena kurang pengetahuan dan perhitungan akhirnya pestisida tersebut malahan dapat meningkatkan populasi hama sehingga tujuan menyelamatkan kerusakan kurang bahkan tidak tercapai (Untung 2000).

Alih teknologi tentang cara pengendalian hama dan penyakit pada tanaman padi perlu diaplikasikan oleh petani. Sistem pengendalian hama terpadu (PHT) adalah suatu konsep atau cara berpikir dalam upaya pengendalian populasi atau tingkat serangan hama dengan menerapkan berbagai teknik pengendalian yang dipadukan dalam satu kesatuan untuk mencegah kerusakan tanaman dan timbulnya kerugian secara ekonomis serta mencegah kerusakan lingkungan dan ekosistem. Dengan kata lain, pengendalian hama terpadu adalah pengendalian hama dan penyakit tanaman dengan pendekatan ekologi yang bersifat multi-disiplin untuk mengelola populasi hama dan penyakit dengan menerapkan berbagai teknik pengendalian yang kompatibel.

Berdasarkan hal tersebut di atas telah diberikan suatu ketrampilan lewat penyuluhan, sehingga setelah dilaksanakannya kegiatan ini petani memiliki tingkat pengetahuan dan pemahaman lebih baik tentang cara pengendalian hama dan penyakit terpadu dan mampu menerapkannya.

\section{METODE}

Desa Mekar Sari merupakan desa binaan Kuliah Kerja Nyata (KKN) tematik Universitas Mahasaraswati Mataram sejak tahun 2017 sampai sekarang. Namun pada saat Mahasiswa melaksanaan KKN di desa tersebut yang dilaksanakan pada bulan Juli tahun 2019, tim penyuluh melihat masih banyaknya petani dalam melaksanakan pengendalian hama dan penyakit tanaman menggunakan pestisida kimia sintetis. Atas dasar tersebut akhir Agustus 2019 tim kembali mengadakan penjajagan ke Kantor Desa Mekar Sari untuk melakukan pembahasan secara umum sampai hal-hal teknis terkait program pengabdian masyarakat, akhirnya bapak kepala desa memberikan ijin untuk melaksanakan pengabdian masyarakat. Sesuai dengan arahan bapak kepala desa penyuluhan dilaksanakan hari senin, tanggal 16 September 2019. Jam 9 pagi sampai jam 12.00 
WITA, dengan merujuk Surat Ketua Prodi Agribisnis Fakultas Pertanian Universitas Mahasaraswati Denpasar Kampus Mataram No 34/Agr_K MTR/IX/2019. Peserta dikuti oleh Petani, ketua kelompok tani dan aparat Desa setempat sebanyak 23 orang.

Sasaran dari penyuluhan ini adalah kepada semua petani yang ada di pedesaan, terutama kelompok tani maju, selain untuk mengembangkan dirinya sendiri juga di harapkan dapat menjadi contoh, memberi masukan-masukan, motivator, innovator bagi masyarakat petani lainnya. Kemudian penyuluhan ini diharapkan dapat bermanfaat bagi petani untuk menyadari pentingnya cara pengendalian hama terpadu, sehingga kerusakan oleh serangan hama dan penyakit dapat diperkecil dan perolehan jumlah produksi dapat meningkat.

Materi ini disampaikan kepada peserta penyuluh dengan teknik ceramah, yang dibantu dengan peralatan white board, LCD, wereless dan pembagian foto copy materi penyuluhan, kemudian disusul dengan sesi tanya jawab atau diskusi-diskusi. Dalam diskusi ini para peserta penyuluhan mengemukakan masalah-masalah yang mereka hadapi serta harapan-harapan yang mereka inginkan khususnya yang menyangkut cara pengendalian hama terpadu. Hal-hal yang dikemukakan oleh peserta penyuluhan di jawab oleh tim penyuluh. Adapun Jawaban-jawaban tim penyuluh, mengarah pada jalan keluar untuk memecahkan masalah yang dihadapi peserta, disertai dengan saran-saran Sebelum pemberian materi penyuluhan, peserta diberikan pertanyaan kepada peserta yang hadir yang bertujuan untuk mengetahui pengetahuan awal tentang edukasi yang diberikan, kemudian setelah diberikan materi, dilakukan evaluasi dengan memberikan pertanyaan yang sama yang bertujuan untuk mengetahui respon penguasaan materi yang telah diberikan

\section{HASIL DAN PEMBAHASAN}

Sebelum penyampaian materi, diawali dengan penyampaian pertanyaan kepada peserta, terkait dengan pengetahuan tentang pengendaliam hama terpadu. Untuk mengetahui pengetahuan peserta disuruh menjawab dengan sangat setuju, setuju dan tidak setuju. Untuk mengetahui pengetahuan peserta yang sangat setuju, peserta mengangkat tangannya setinggi-tingginya, kemudian yang setuju mengangkat tangannya setinggi kepala dan yang tidak setuju tidak perlu mengangkat tangan.

Dari hasil pertanyaan yang disampaikan kepada peserta, sebagian besar peserta yaitu 10 (43.48 $\%)$ memiliki pengetahuan yang kurang tentang pengendalian hama dan penyakit, 8 orang $(34.78 \%)$, memiliki pengetahuan yang cukup dan 5 orang (21.74\%) memiliki pengetahuan yang baik terhadap cara pengendalian hama dan penyakit.

Setelah penyapaian pertanyaan kepada peserta penyuluh, dilanjutkan dengan proses selanjutnya yaitu dilaksanakan penyampaian materi pengendaian hama terpadu pada tanaman padi, yang dilanjutkan dengan sesi tanya jawab/diskusi. Beberapa pertanyaan yang diajukan oleh peserta penyuluhan adalah sebagai berikut:

1. Tanaman padi sering diserang oleh hama utama, hama kedua, hama potensial dan hama hama migran. Itu maksudnya apa

2. Apa maksudnya ambang ekonomi apa ada patokan atau ukuran bahwa tanaman padi segera untuk disemprot pestisida

3. Mengapa terjadi resurjensi hama.

4. Dengan penerapan pengendalian hama terpadu, apakah tidak dibolihkan lagi menggunakan obat kimia sintetis.

5. Faktor -faktor lingkungan apa saja yang dapat berpengaruh terhadap ledakan penyakit

6. Usaha-usaha apa saja yang dapat dilaksanakan petani untuk pengelolaan hama terpadu 
Untuk pertanyaan pertama diberikan penjelasan bahwa: a). Hama-hama utama adalah hama hama yang selalu menyerang pada suatu daerah dengan intensitas serangan yang berat sehingga selalu memerlukan usaha pengendalian. Kelompok hama ini mendatankan kerugian bagi petani, biasanya pada suatu agroekosistem hanya terdapat satu atau dua hama utama. Tanpa ada usaha pengedalian hama-hama tersebut akan selalu berada di atas jenjang atau arus toleransi ekonomis, b). Hama-hama kedua maksudnya hama-hama yang relatif kurang penting, tetapi kadang-kadang populasinya pada suatu waktu dan sempat meningkatkan melebihi arah toleransi ekonomisnya. Dengan kata lain hama yang pada keadaan normal akan menyebabkan kerusakan yang kurang berarti tetapi kemungkinan adanya perubahan ekosistem akan meningkatkan populasi sehingga intensitas serangan sangat merugikan. Dengan demikian status hama tersebut berubah menjadi hama utama, c). Hama-hama potensial merupakan sebagian besar jenis serangga herbivora yang saling berkompetisi dalam memperoleh makanan. Kelompok hama ini, tidak mendatangkan kerugian yang berarti dan tidak membahayakan dalam kondisi pengelolaan agroekosistem yang normal. Namun karena kedudukannya dalam rantai makanan, kelompok populasi hama ini berpotensi meningkat dan dapat menjadi hama yang membahayakan, d). Hama migran merupakan hama yang tidak berasal dari agroekosistem setempat. Kelompok hama ini datang dari luar, dan sifatnya berpindah-pindah (migran). Kelompok hama migran jika datang pada suatu tempat dapat menimbulkan kerusakan yang berarti. Namun hanya dalam jangka waktu yang pendek, karena akan berpindah ke daerah lain.

Kemudian pertanyaan yang kedua tentang pertanyaan ambang ekonomi diberi penjelasan: yang dimaksud dengan ambang ekonomi atau ambang pengendalian, atau ambang toleransi ekonomi adalah ketetapan tentang pengambilan keputusan tentang kapan harus dilaksanakan pengendalian dengan penggunaan obat kimia sintetis (pestisida). Apabila populasi atau kerusakan hama belum mencapai aras toleransi, maka penggunaan pestisida masih belum di perlukan.

Kemudian dilanjutkan dengan penjelasan: secara fisiologi petani bisa menerapkan prinsip ambang ekonomis,yang artinya kapan petani harus melakukan pengedalian hama dengan melihat contoh-contoh di bawah ini:

1. Apabila tanaman padi diserang wereng coklat di mana terlihat imago 5 sektor/rumpun pada tanaman berumur 40 hari dan 20 ekor/rumpun apabila tanaman telah berumur 40 hari setelah tanam.

2. Untuk wereng hijau, imago sebanyak 10 ekor/10 ayunan jarring.

3. Walang sangit,imago 2 ekor per $\mathrm{m}^{2}$

4. Hama ganjur. Jika serangannya $5 \%$ pada tanaman berumur 40 hari setelah tanam.

5. Hama putih palsu jika intensitas serangan $10 \%$

6. Ulat grayak, jika ada 2 ekor ulat $/ \mathrm{m}^{2}$

7. Penggerek batang padi, jika intensitas serangannyasundep/ beluk mencapai $10 \%$ atau 1-2 kelompok telur $/ \mathrm{m}^{2}$

Apabila tanaman padi bapak petani ada salah satu gejala serangan hama seperti hal tersebut di atas, maka petani harus mengendalikanya.

Atas pertanyaan ketiga mengapa resurjunsi dapat terjadi: penjelasan yang diberikan adalah: resurjensi ini dapat terjadi karena terbunuhnya musuh alami oleh pestisida yang di gunakan umumnya berspekrum lebar dan tidak selektif. Dengan berkurang atau matinya musuh alami maka populasi hama yang ada akan menjadi bebas atau tidak terhalang untuk meningkat, karena kurang berfungsinya pengendali-pengendali alami. Contoh kalau menyemprot padi yang makan wereng akan ikut mati.

Kemudian atas pertanyaan yang ke empat diberikan penjelasan bahwa: sebenarnya petani tidak dilarang kalau menggunakan obat kimia sintetis, tetapi pengendalian hama dan penyakit tanaman secara kimiawi adalah alternatif terakhir apabila cara-cara pengendalian yang lain tidak mampu mengatasi peningkatan populasi hama yang telah melampaui ambang kendali. Tujuan penggunaan pestisida merupakan koreksi untuk menurunkan populasi hama atau penyakit sampai pada batas keseimbangan. Penggunaan pestisida juga harus tepat sasaran, tepat dosis dan tepat waktu. 
Atas petanyaan kelima diberikan penjelasan, bahwa yang dimaksud: faktor lingkungan yang dapat memberikan pengaruh terhadap timbulnya suatu penyakit. Faktor lingkungan tersebut berupa suhu udara, intensitas dan lama curah hujan, intensitas dan lama embun, suhu tanah, kandungan air tanah, kesuburan tanah, kandungan bahan organik, angin, api, dan pencemaran air. Faktor lingkungan memberikan pengaruh terhadap pertumbuhan tanaman inang dan menciptakan kondisi yang sesuai bagi kehidupan jenis patogen tertentu.

Atas pertanyaan ke enam usaha-usaha apa yang dilaksanakan oleh petani untuk pengelolaan hama terpadu. Menurut Pemintel (1986), usaha-usaha yang dilaksanakan adalah: petani memilih tanaman yang resisten, memanipulasi ketahanan jenis tanaman yang akan dibudidayakan, mengusahakan lingkungan pertanaman agar mengurangi serangan patogen, serta melakukan kegiatan dalam pengelolaan tanaman (pengaturan jarak tanam, pencampuran jenis, penjarangan)

Setelah dilaksanakan penyampaian materi dan diskusi, dilaksanakan evaluasi dengan memberikan pertanyaan yang sama tentang pengetahuan tentang pengendalian hama dan penyakit terpadu. Ternyata pengetahun peserta penyuluh menjadi meningkat yaitu 20 orang (86.95\%), memiliki pengetahun yang baik, terhadap cara mengendalikan hama terpadu, 2 orang $(8.70 \%)$ memiliki pengetahuan cukup dan 1 orang (4.35\%) memiliki pengetahuan yang kurang (Gambar 1).

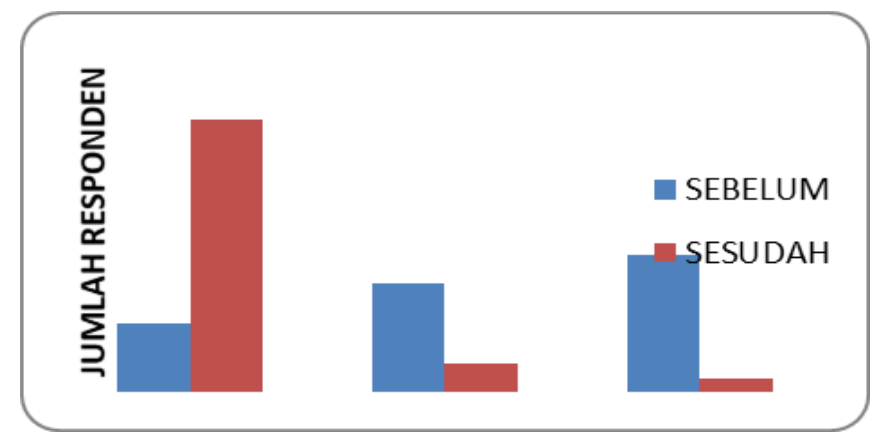

Gambar 1. Grafik perubahan tingkat pengetahuan responden sebelum dan sesudah dilaksanakan penyuluhan

Selain dilaksanakan evaluasi terhadap pengetahuan peserta penyuluhan, juga dapat disampaikan sebagai berikut:

1. Penerimaan oleh kepala desa cukup baik, yaitu menyediaan tempat di Balai Desa dan menghubungi para peserta sebagai peserta penyuluhan.

2. Peserta cukup bergairah dalam mengikuti acara penyuluhan dari awal hingga akhir

Selain hal tersebut di atas dari hasil pengamatan tim penyuluh dapat pula dikemukakan faktor penghambat dan pendorong dari usaha penyuluhan ini.

Beberapa hambatan yang perlu disampaikan pada laporan ini adalah ketapatan waktu pelaksanaan penyuluhan. Hambatan yang pertama adalah kesiapan sarana penyuluh di lokasi. Kami tim penyuluh sudah stand bay di lokasi sesuai jadwal dan persiapan sarana seperti Meja,latop dan LCD sudah memadai. Pelaksanaan penyuluhan ini semula direncanakan di dalam ruangan namun pelaksanaan dilakukan di luar ruangan sehingga pada saat penyampaian materi tidak bisa berjalan sesuai harapan. Situasi dan kondisi yang sangat terbatas ini maka penyampaian materi belum bisa maksimal. Hambatan yang kedua adalah dari masyarakat setempat yaitu keterlambatan kehadiran di lokasi penyuluhan, hal ini disebabkan sebagian besar masyarakat melakukan kegitan rutinitas sebagai petani

Kemudian dari faktor pendorong, yang paling memotivasi kami dari tim penyuluh adalah kehadiran bapak Kepala Desa Mekar Sari beserta staf, tiba di lokasi tepat waktu. Meskipun baru sebagian peserta yang hadir, beliau menyarankan agar jadwal penyuluhan di tunda beberapa menit, 
dan bapak kepala desa sangat optimis bahwa masyarakat pasti datang. Selain itu juga dilihat dari jalannya penyuluhan ini, peserta penyuluhan nampaknya bergairah. Hal ini terbukti dari ketekunan peserta mengikuti seluruh kegiatan dari awal sampai akhir dan adanya saling tanya jawab, sehingga tim penyuluh berpikir bahwa materi sesuai dengan masalah yang dihadapi petani dan cukup tanggap. Adanya rasa saling membutuhkan antara tim dan peserta, dimana dirasa mampu menumbuhkan jalinan kerja sama, baik pada saat berlangsungnya penyuluhan maupun dimasa yang akan datang

\section{KESIMPULAN DAN SARAN}

\section{Kesimpulan}

Kegiatan penyuluhan pertanian di Desa Mekar Sari Kecamatan Gunung Sari berjalan dengan lancar dan sebagian besar peserta penyuluhan dapat meningkatkan pengetahuan menjadi lebih baik, sehingga diharapkan dapat meningkatkan pemahamannya dan mampu menerapkan teknologi tersebut.

\section{Saran}

Pelaksanaan PHT harus sesuai dengan keadaan ekosistem dan sosial ekosistem masyarakat setempat, karena konsepsi PHT pada dasarnya merupakan penerapan pendekatan-pendekatan ekologi dan ekonomi pengedalian hama untuk itu diperlukan kerjasama dengan penyuluh setempat.

\section{Ucapan Terima Kasih}

Ucapan terima kasih disampaikan kepada LPPM Unmas Denpasar yang telah mendukung untuk pelaksanaan pengabdian dan juga Bapak Kepala Desa Mekar Sari dan jajarannya, sehingga kegiatan ini dapat terwujud tanpa ada hambatan.

\section{DAFTAR PUSTAKA}

Cantrell. 2004. New technologies for rice farmers. ICM Edition, Bayer Crop

Nuryanto, B, 2018. Pengendalian Hama Penyakit Tanaman Padi Berwawasan Lingkungan Melalui Pengelolaan Komponen Epidemik. Jurnal Pertanian. Balai Besar Penelitian Tanaman Padi Jal an Raya IX, S ukama ndi, Sub ang, Jawa Bara t

Pimentel. 1996. Perspektife of integreeted pest management crop protecton. Iowa state Jour of Res.

Semangun, H. 2008 Penyakit - penyakit Tanaman Pangan di Indonesia.Gadjah Mada University Press. Yogyakarta

Untung, K .2000. Pengantar Analisis Ekonomi Pengedalian Hama Terpadu.Andi offset Yogyakarta. 